\title{
Identification of Upregulated SCG10 mRNA Expression Associated with Late-Phase Long-Term Potentiation in the Rat Hippocampal Schaffer-CA1 Pathway In Vivo
}

\author{
Haixiang Peng, Brian E. Derrick, and Joe L. Martinez Jr \\ Cajal Neuroscience Institute, Department of Biology, University of Texas, San Antonio, Texas 78249-0662
}

\begin{abstract}
The maintenance of long-term potentiation (LTP) depends on alteration of gene transcription. By screening a subtracted cDNA library that is enriched in upregulated transcripts in rat hippocampus $3 \mathrm{hr}$ after Schaffer-CA1 LTP induction in vivo, we identified a neural growth-associated protein SCG10 (superior cervical ganglia clone 10) gene. The semiquantitative reverse transcription-PCR and Northern blot experiments confirmed that SCG10 mRNA levels were elevated in tetanized rat hippocampi compared with those of sham controls that received only low-frequency stimulation. Both 1 and $2 \mathrm{~kb}$ forms of SCG10 mRNAs contributed to the increased expression. Using a riboprobe with a sequence specific to the $3^{\prime}$-untranslated region of rat SCG10 mRNA, in situ hybridization further revealed a significant increase of the SCG10 mRNA $2 \mathrm{~kb}$ form in the ipsilateral CA3 and CA1 regions of LTP animals. In addition, we systemically injected the competitive NMDA receptor antagonist $\mathrm{D}, \mathrm{L}-3[( \pm)$-2-carboxypiperazine-4-yl]-propyl-1-phosphonic acid (CPP) to determine whether the alteration of SCG10 expression depends on NMDA receptor activation or tetanus alone. Administration of CPP $1 \mathrm{hr}$ before tetanus completely blocked LTP induction and the increase of SCG10 mRNA levels. Thus, these results suggest that the transcription of SCG10 in vivo is regulated by long-lasting synaptic activity and may contribute to the maintenance of long-term synaptic plasticity via a presynaptic remodeling mechanism.
\end{abstract}

Key words: long-term potentiation; SCG10; gene expression; transcription; hippocampus; synaptic plasticity; NMDA receptor; CA1; CA3; neural growth-associated protein

\section{Introduction}

Long-term potentiation (LTP) is a persistent increase in synaptic strength that is produced by brief high-frequency stimulation at excitatory afferents. Since its discovery by Bliss and Lømo (1973) in rabbit hippocampus, LTP is considered the best model for studying the neural mechanisms underlying learning and memory (Martinez and Derrick, 1996). As with memory storage in intact animals, LTP in the hippocampal Schaffer collateral-CA1 pathway has distinct temporal phases (Nguyen et al., 1994): the early phase of LTP lasts $1-3 \mathrm{hr}$, requiring only covalent modification of preexisting proteins; the late-phase LTP induced by repeated tetanic stimulation persists for at least several hours and is dependent on new RNA transcription and protein translation. Thus, altered gene expression is believed to be crucial for the development of LTP from the potentiated state of the synapses at the early stage to the more stabilized form and for further maintenance. The genes induced during the expression of synaptic plasticity are also classified temporally into two groups: immediate-early genes (IEGs) and late-responding genes (Abraham et al., 1991; Dragunow, 1996). In the first hours after LTP induc-

\footnotetext{
Received 0ct. 28, 2002; revised May 29, 2003; accepted May 29, 2003.

This work was supported by National Institutes of Health (NIH) Grant DA04195, Research Centers in Minority Institutions Grant RR1 3646, the Ewing Halsell Endowment (J.L.M.), and NIH Grant DA11983 (B.E.D.).

Correspondence should be addressed to Haixiang Peng, Department of Biology, University of Texas at San Antonio, 6900 North Loop 1604 West, San Antonio, TX 78249-0662. E-mail: hpeng@lonestar.utsa.edu.

Copyright $\odot 2003$ Society for Neuroscience $\quad$ 0270-6474/03/236617-10\$15.00/0
}

tion, the stimulation of cell surface receptors and subsequent activation of cytoplasmic second messenger systems result in a rapid but transient activation of IEG transcription (Walton et al., 1999). Most of these transcripts encode transcription factors (Lanahan and Worley, 1998). Once translated, these inducible transcription factors reenter the nucleus and regulate the expression of late-responding genes. Currently, we know very little about the identity of the late-responding genes. The identification of these genes and their functions may help unveil the molecular mechanisms of the long-term information storage in neurons.

In the present study, a subtracted cDNA library was used to screen the late-responding genes upregulated by late-phase LTP ( $3 \mathrm{hr}$ after tetanus) in rat hippocampus. We identified SCG10 (superior cervical ganglia clone 10), a neural growth-associated protein (nGAP; Stein et al., 1988a), as one of these genes and determined that an increase in SCG10 mRNA expression followed NMDA receptor-dependent LTP induction in the Schaffer-CA1 pathway. SCG10 was originally identified by its neuronspecific expression during neural crest development (Anderson and Axel, 1985). SCG10 is a membrane-associated phosphoprotein (Stein et al., 1988a; Antonsson et al., 1997, 1998). The expression of SCG10 mRNA and the expression of the protein are both developmentally regulated, and its protein is highly concentrated in the central domain of growth cones (Stein et al., 1988a). In adult brain, SCG10 only persists in certain subsets of neurons 
with long projections or extensive dendritic arbors, such as pyramidal and granule cells in the hippocampus (Himi et al., 1994a,b). Previous studies (Himi et al., 1994a; Riederer et al., 1997) suggest that SCG10 plays a role in remodeling synaptic terminals in response to various intrinsic and extrinsic signals in adult brains. Here we used semiquantitative reverse transcription (RT)-PCR, Northern blot, and in situ hybridization to determine the expression patterns of the SCG10 gene associated with latephase LTP in the rat hippocampal Schaffer-CA1 pathway in vivo.

\section{Materials and Methods}

Animals. Inbred male Fisher 344 rats (Charles River, Raleigh, NC) aged 3-4 months were housed individually in accordance with the guidelines of the Department of Biology of the University of Texas at San Antonio, with food and water available ad libitum. The animals were maintained on a $12 \mathrm{hr}$ light/dark cycle.

Electrophysiology. Animals were anesthetized with pentobarbital (50 $\mathrm{mg} / \mathrm{kg}$, i.p.) and given booster pentobarbital injections $(15 \mathrm{mg} / \mathrm{kg})$ at 30 min intervals to maintain a surgical level of anesthesia. Body temperature was maintained at $37^{\circ} \mathrm{C}$ with a heating pad. The head was mounted in a stereotaxic frame, and both the skin and fascia were retracted to expose the skull under sterile conditions. The tissue was kept moist with gauze moistened with sterile saline throughout the surgical procedures. The monopolar stimulating electrode consisted of a single Teflon-coated stainless steel wire $(0.005$ inch diameter) exposed only at the tip. The recording electrode was an insulated stainless steel wire with a 2-5 M $\Omega$ impedance. For delivery of constant current stimulation, $10-600 \mu \mathrm{A}$ monophasic pulses (0.1-0.25 msec duration) were provided by a Grass stimulator (Grass Instrument Co., Quincy, MA) and delivered to the stimulating electrodes through a Grass stimulus isolation unit. The stimulating electrode was placed in the Schaffer collaterals in the stratum radiatum [anteroposterior (AP), $4.0 \mathrm{~mm}$; mediolateral $(\mathrm{ML}), 3.3 \mathrm{~mm}$ ] of the right hemisphere, and field potentials were recorded by a single recording electrode also placed in the stratum radiatum (AP, $4.5 \mathrm{~mm}$; ML, $3.4 \mathrm{~mm}$ ) of the ipsilateral dorsal hippocampal CA1 region.

Dorsoventral (DV) coordinates for the stimulating and recording electrodes were determined as follows. A recording electrode was placed initially in the CA1 pyramidal cell layer (DV, $2.3 \mathrm{~mm}$ ), verified with audio monitoring of injury-induced cell discharge. The stimulating electrode then was lowered into the Schaffer collaterals (DV, $2.5 \mathrm{~mm}$ ) with stimulation delivered at a rate of $0.1 \mathrm{~Hz}$ until a maximal CA1 field EPSP (fEPSP) was observed. All evoked responses were extracellular recordings referenced to a screw mounted on the anterior skull and amplified on a Grass $\mathrm{P} 3$ series AC preamplifier, filtered at $0.1 \mathrm{~Hz}-10 \mathrm{kHz}$, digitized (5 points $/ \mathrm{msec}$ ) using a microcomputer, and stored for off-line analysis using DataWave (Thornton, CO) software. The magnitude of the fEPSP response was measured by the EPSP slope occurring between 1 and 3 msec after response onset. At the start of each experiment, maximal responses for each animal were evoked using up to a $150 \mu \mathrm{A}$ current. The current intensity $(20-40 \mu \mathrm{A})$ eliciting a $50 \%$ maximal response was determined and used for all subsequent stimulation, including induction of LTP. Low-frequency responses then were evoked once every $15 \mathrm{sec}$ throughout a $15 \mathrm{~min}$ baseline period and for an additional $1 \mathrm{hr}$ after train delivery. LTP was induced in the Schaffer collateral-CA1 pathway by delivery of three $1 \mathrm{sec}$ trains of $100 \mathrm{~Hz}$ stimulation, with an intertrain interval of $5 \mathrm{~min}$. Initial slopes of EPSPs were measured off-line and expressed as the percent change from baseline, which was calculated as the average of the last 15 min of baseline recordings. Tetanus-induced changes in fEPSP slopes were measured 55-60 min after the last train of high-frequency stimulation and were compared with baseline responses recorded during the $5 \mathrm{~min}$ period immediately before delivery of the first train. The significant differences between and within groups were estimated by using two-way ANOVA (stimulation $\times$ group) with highfrequency stimulation (before and after) as the repeated measure, followed by post hoc Bonferroni $t$ tests. The probability levels interpreted as statistically significant were $p<0.05$. Data are presented as group means \pm SEM.

To confirm that the synaptic response is still potentiated $3 \mathrm{hr}$ after tetanus, the low-frequency responses were evoked and recorded once every $15 \mathrm{sec}$ for $3 \mathrm{hr}$ after train delivery. The averages of the last $5 \mathrm{~min}$ fEPSP slopes at 1 and $3 \mathrm{hr}$ after tetanus were calculated, and the significant differences from baseline were assessed by one-way repeated measures ANOVA, followed by post hoc Bonferroni $t$ tests. These animals were not used in the following molecular biology studies.

Drugs. The competitive NMDA receptor antagonist D,L-3[( \pm$)-2-$ carboxypiperazine-4-yl]-propyl-1-phosphonic acid (CPP) was obtained from Research Biochemicals (St. Louis, IL). CPP was dissolved in sterile saline solution and administered intraperitoneally in doses of $10 \mathrm{mg} / \mathrm{kg}$, as determined by our previous in vivo studies (Hernandez et al., 1994), at least $1 \mathrm{hr}$ before delivery of trains. The animals in LTP and sham groups only received a saline injection.

Verification of electrode placement. Electrode placement was verified histologically at the end of the study. The rats were killed with an overdose of pentobarbital and perfused intracardially with saline. The brains were extracted and stored at $-80^{\circ} \mathrm{C}$. The frozen sections $(25 \mu \mathrm{m})$ were cut coronally, mounted, and stained with thionin.

Isolation of total RNA. Three hours after LTP induction, whole ipsilateral hippocampi (including dentate gyrus) were dissected in ice-cold $1 \times$ PBS (Invitrogen, Grand Island, NY) and snap-frozen at $-80^{\circ} \mathrm{C}$. The frozen tissue was homogenized, and the total RNA was isolated with $1 \mathrm{ml}$ of TriPure isolation reagent from Roche Molecular Biochemicals (Indianapolis, IN) according to the instructions of the manufacturer, quantified by UV spectrophotometry.

Selection of upregulated genes from a cDNA subtraction library. Poly $\left(\mathrm{A}^{+}\right)$mRNA was extracted from the pooled total RNA using a Oligotex mRNA kit from Qiagen (Chatsworth, CA). The purified mRNA from the tetanized or the untetanized animals was used as tester or driver, respectively, to generate a subtracted cDNA library with the PCR-Select cDNA subtraction kit (Clontech, Palo Alto, CA) according to the instructions of the manufacturer. The subtracted and amplified PCR products were directly subcloned into pGEM-T Easy vector (Promega, Madison, WI). For a $10 \mu \mathrm{l}$ ligation reaction, $50 \mathrm{ng}$ of vector was ligated with $2 \mu \mathrm{l}$ of PCR products and incubated at $16^{\circ} \mathrm{C}$ overnight. Then $4 \mu \mathrm{l}(20 \mathrm{ng})$ of ligated plasmid was added to $50 \mu \mathrm{l}$ of Epicurian Coli XL1-Blue supercompetent cells (Stratagene, La Jolla, CA) and incubated on ice for $30 \mathrm{~min}$. After a $45 \mathrm{sech}$ heat shock at $42^{\circ} \mathrm{C}, 450 \mu \mathrm{l}$ of $\left(42^{\circ} \mathrm{C}\right) \mathrm{SOC}$ medium (Novagen, Madison, WI) was added and incubated at $37^{\circ} \mathrm{C}$ for $1 \mathrm{hr}$ with shaking at 225-250 rpm. Finally, the cells were transformed to Luria-Bertani (LB)-ampicillin 5-bromo-4chloro-3-indolyl $\beta$-D-galactopyranoside agar plates and incubated at $37^{\circ} \mathrm{C}$ overnight. An individual positive (white) bacterial colony was picked from the subtracted cDNA library and used to inoculate $5 \mathrm{ml}$ of LB broth, $\mathrm{pH} 7.0$, containing $50 \mu \mathrm{g} / \mathrm{ml}$ ampicillin and incubated at $37^{\circ} \mathrm{C}$ with shaking $(250$ $\mathrm{rpm}$ ) overnight. A $1.5 \mathrm{ml}$ aliquot was used to purify the plasmids with a Promega Wizard Plus Minipreps DNA purification system according to the manufacturer's instructions. The inserts were released from plasmids using the restriction enzyme EcoRI and visualized on an agarose gel.

DNA sequencing. Plasmid DNA sequencing of cloned cDNA fragments was performed using the Sequenase V2.0 DNA sequencing kit (United States Biochemicals, Cleveland, $\mathrm{OH}$ ) with either a T7 forward sequencing primer or an SP6 reverse primer. Five micrograms of purified plasmid were subjected to alkaline denaturation by the addition of 0.1 volume of freshly prepared $2 \mathrm{~N} \mathrm{NaOH}$ and $2 \mathrm{~mm}$ EDTA. The samples were incubated at $37^{\circ} \mathrm{C}$ for $30 \mathrm{~min}$, precipitated with ethanol, and resuspended in $7 \mu \mathrm{l}$ of sterile deionized $\mathrm{H}_{2} \mathrm{O}$. Two microliters of Sequenase reaction buffer and $1 \mu \mathrm{l}$ of primer (1 pmol) were added to the denatured DNA, incubated for $2 \mathrm{~min}$ at $65^{\circ} \mathrm{C}$, and then allowed to cool to $37^{\circ} \mathrm{C}$ over 30 $\mathrm{min}$. The labeling and termination steps were as instructed by the manufacturer using $\left[\alpha-{ }^{33} \mathrm{P}\right] \mathrm{dATP}$. The sequence reaction products were resolved on a polyacrylamide denaturing electrophoretic gel ( $6 \%$ acrylamide and $7 \mathrm{~m}$ urea) run at $60 \mathrm{~mA}$ and visualized by autoradiography. Sequence results were analyzed with the program Seqaid and compared with previously reported sequences in the National Center for Biotechnology Information database using the BLAST and FASTA search programs.

Semiquantitative RT-PCR and Southern analysis. The RNA samples were treated with $1 \mu \mathrm{l}$ of DNase I ( $2 \mathrm{U} / \mu \mathrm{l}$; Ambion, Austin, TX) to remove contaminating genomic DNA. First-strand cDNA was generated 
from total RNA (10 $\mu \mathrm{g})$ using Moloney murine leukemia virus reverse transcriptase, random primers, and reagents supplied with the ProSTAR first-strand RT-PCR kit (Stratagene). One microliter of the reaction (50 $\mu \mathrm{l}$ ) was used in a $50 \mu \mathrm{l}$ PCR amplification using a master mix containing $2 \mathrm{U}$ of AmpliTaq DNA polymerase (PerkinElmer Life Sciences, Foster City, CA) inactivated by Clontech TaqStart antibody, $200 \mu \mathrm{M}$ dNTPs, and $400 \mu \mathrm{M}$ gene-specific primers. PCR was performed as follows: $24-34$ cycles of $30 \mathrm{sec}$ at $94^{\circ} \mathrm{C}, 30 \mathrm{sec}$ at $56^{\circ} \mathrm{C}$, and $1.5 \mathrm{~min}$ at $72^{\circ} \mathrm{C}$, followed by $10 \mathrm{~min}$ at $72^{\circ} \mathrm{C}$. The linear range of PCR amplification for each primer pair was determined according to the manufacturer's instructions (Ambion). In all PCR reactions, $18 \mathrm{~S}$ ribosomal RNA was used as endogenous control. Internal control primers with an optimal ratio of $18 \mathrm{~S}$ primer pair/18S competimer (200 $\mu \mathrm{M}$; Ambion) were added to each reaction tube to ensure that the amplifications of experimental and $18 \mathrm{~S}$ cDNAs were within the linear ranges at the end of reactions. The primer pair specific to the SCG10 $2 \mathrm{~kb}$ isoform (forward, SCG102kf, 5'-CAG GCA TTC GAT GTT GTG TC-3'; reverse, SCG102kr, 5' -CAG GCA AAA GCT TAA AAC GAA- $3^{\prime}$ ) amplified a $600 \mathrm{bp}$ fragment corresponding to the 3 '-untranslated region (UTR) of SCG10 mRNA (bases 917-1513), and another SCG10 gene-specific primer set (forward, SCG101kf, 5'-GCA ATG GCC TAC AAG GAA AA-3'; reverse, SCG101kr, 5' -ATT TAC TAT GGG AGG GGC GT-3') amplified a 566 bp sequence in the coding region (bases 101-666), which is common to both 1 and $2 \mathrm{~kb}$ isoforms. PCR products were visualized on $1.5 \%$ agarose-Tris-acetate-EDTA electrophoresis buffer gels and blotted to a Dupont (Wilmington, DE) GeneScreen hybridization transfer membrane overnight, followed by UV cross-linking. The probe corresponding to the $2 \mathrm{~kb}$ form of SCG10 mRNA was generated from the original plasmid containing the $3^{\prime}$-UTR cDNA fragment of rat SCG10 mRNA (bases 821-1520). To make a probe for the coding region of SCG10 mRNA, which would hybridize to both 1 and $2 \mathrm{~kb}$ transcripts, the RT-PCR product amplified by the primers SCG101kf and SCG101kr was extracted from agarose gel with QIAEXII kit (Qiagen), subcloned into the pGEM-T Easy vector (Promega), and transformed into Epicurian Coli XL1-Blue supercompetent cells (Stratagene) as described above. The cDNA fragment corresponding to bases $101-666$ of rat SCG10 mRNA was verified by sequencing. The probe for $18 \mathrm{~S}$ DNA was also generated by the same procedures. The insert cDNA fragments were released from plasmids using the appropriate restriction enzyme and labeled with a random-primed DNA-labeling kit (Invitrogen) and $50 \mu \mathrm{Ci}$ of $\left[\alpha^{-}{ }^{32} \mathrm{P}\right] \mathrm{dCTP}$, followed by purification with G-50 Sephadex columns (Roche Molecular Biochemicals). The membranes were prehybridized for at least $3 \mathrm{hr}$ at $42^{\circ} \mathrm{C}$ in prehybridization buffer ( $6 \times$ SSC, $0.5 \%$ SDS, $5 \times$ Denhardt's reagent, $50 \%$ formamide, and 0.5 $\mathrm{mg} / \mathrm{ml}$ denatured salmon sperm DNA). The hybridization was performed overnight at $42^{\circ} \mathrm{C}$ in hybridization buffer with a $2 \times 10^{6} \mathrm{cpm} / \mathrm{ml}$ cDNA probe. The membranes were washed for 5 min twice in $2 \times$ SSC and $0.1 \%$ SDS at room temperature and then given two washes of $5 \mathrm{~min}$ in $0.2 \times$ SSC and $0.1 \%$ SDS at room temperature, followed by a moderate wash at $42^{\circ} \mathrm{C}$ with $0.2 \times$ SSC and $0.1 \%$ SDS, and the membranes were then exposed to $\mathrm{x}$-ray film for $1 \mathrm{~d}$.

Northern blot analysis. Total RNA $(10 \mu \mathrm{g})$ from the whole ipsilateral hippocampi (including dentate gyrus) of the tetanized or untetanized animals was fractioned by electrophoresis through $1.0 \%$ denaturing agarose gels and capillary-transferred to the BrightStar Plus nylon membrane using a NorthernMax Complete Northern blotting kit (Ambion) according to the manufacturer's instructions. The ribosomal 28 and $18 \mathrm{~S}$ bands were stained with methylene blue as a control to estimate the loaded amount of RNA samples. To make the riboprobe, the plasmid containing the cDNA insert corresponding to the coding region of the SCG10 gene (see RT-PCR), which hybridizes to both 1 and $2 \mathrm{~kb}$ transcripts, was linearized with the restriction enzyme HincII and labeled by $\left[\alpha-{ }^{32} \mathrm{P}\right]$ UTP with an Ambion Strip-EZ RNA StripAble RNA probe synthesis and removal kit. Hybridization and membrane washing conditions were performed as described in the manufacturer's instructions (Ambion). The membrane was exposed to $\mathrm{x}$-ray film (Fuji) for $3 \mathrm{~d}$.

In situ hybridization analysis. Three hours after LTP induction, the brains were obtained and frozen immediately at $-80^{\circ} \mathrm{C}$. Eightmicrometer-thick coronal sections were cut in a cryostat, placed onto poly-L-lysine precoated slides (Fisher Scientific, Houston, TX), and kept frozen until further processing. The riboprobes of antisense and sense were generated from the plasmid-containing cDNA fragment corresponding to the $3^{\prime}$-UTR region of the rat SCG10 gene (see RT-PCR). The plasmid was linearized with the restriction enzyme BalI and labeled by the Ambion Strip-EZ RNA StripAble RNA probe synthesis and removal kit with SP6 or T7 RNA polymerase to produce a 300- to 400-bp-long antisense or sense probe, respectively. The manufacturer's instructions were followed, except that $10 \mathrm{~mm}$ CTP and $10 \mu \mathrm{M}$ UTP were used. For in situ hybridization, the slides were allowed to warm up to room temperature and were fixed in $4 \%$ electron microscopy-grade paraformaldehyde (Electron Microscopy Sciences, Fort Washington, PA) for $20 \mathrm{~min}$. Next, the sections were treated with fresh proteinase $\mathrm{K}(20 \mu \mathrm{g} / \mathrm{ml})$ in 50 $\mathrm{mm}$ Tris- $\mathrm{HCl}, \mathrm{pH} 8.0$, and $5 \mathrm{~mm}$ EDTA for $2-5 \mathrm{~min}$ at room temperature, followed by a 5 min wash in PBS and a 5 min incubation in $0.2 \mathrm{~N} \mathrm{HCl}$ to disrupt ribosomes that could be bound to mRNA. The sections were then refixed in $4 \%$ paraformaldehyde for $20 \mathrm{~min}$ and quickly washed with RNase-free water. To diminish probes binding to protein moieties and thus reduce background hybridization, the tissue sections were acetylated in $300 \mathrm{ml}$ of $0.1 \mathrm{M}$ triethanolamine, $\mathrm{pH} 8.0$, containing $0.75 \mathrm{ml}$ of acetic anhydride and incubated for $10 \mathrm{~min}$. The slides were then washed in PBS and $0.85 \%$ saline for 5 min each and incubated in equilibration solution from a Suresite in situ hybridization kit (Novagen) for $10 \mathrm{~min}$ at room temperature. Next, the slides were incubated in the prehybridization solution (Novagen) at $50^{\circ} \mathrm{C}$ for at least $1 \mathrm{hr}$ and dehydrated by quickly washing them for 2 min each through a $60,80,95$, and $99 \%$ ethanol series prepared with RNase-free water, except that the $95 \%$ wash was done for 5-10 min to avoid salt depositing on the dehydrated slides. The sections were allowed to air dry and were then used immediately for in situ hybridization. The hybridization solution (Novagen), containing $10^{6} \mathrm{cpm}$ of either sense or antisense riboprobes labeled by $\left[\alpha^{-33} \mathrm{P}\right] \mathrm{UTP}$ per slide, was heated to $80^{\circ} \mathrm{C}$, placed on ice for $1 \mathrm{~min}$, and pipetted onto the sections, which were then covered with coverslips. The slides were placed horizontally in a slide box containing a tissue paper soaked with $5 \mathrm{ml}$ PBS. The slides were then incubated in a hybridization oven at $50^{\circ} \mathrm{C}$ for at least $18 \mathrm{hr}$. Next, the coverslips were removed from the brain sections by washing the slides vertically in $2 \times \mathrm{SSC}$ at $50^{\circ} \mathrm{C}$ for $30 \mathrm{~min}$. Then the sections were incubated with $200 \mu \mathrm{g} / \mathrm{ml} \mathrm{RNase} \mathrm{A} \mathrm{(Sigma,} \mathrm{St.} \mathrm{Louis,} \mathrm{MO)} \mathrm{at} 37^{\circ} \mathrm{C}$ for $30 \mathrm{~min}$ to reduce the background of nonspecific probe binding. This was followed by serial washings as instructed by the manufacturer (Novagen). The sections were dehydrated in ethanol, allowed to air dry, and autoradiographed, along with ${ }^{14} \mathrm{C}$-radioactive standards, on $\beta$-Hypermax film (Amersham Biosciences, Arlington Heights, IL).

Semiquantitative analysis of the film was performed using a microcomputer imaging device M2 imaging system (Imaging Research, Ontario, Canada) to measure relative optical density (ROD) values. All data were obtained from the same in situ hybridization experiment in a blind manner. Measurements were taken within the linear range of optical density levels and expressed in arbitrary units. Bilateral measurements were taken from manually selected hippocampal areas: the principal cell layers of CA1, CA3, and the dentate gyrus. Using the observation that expression levels of SCG10 mRNA in cerebral cortex did not vary after high-frequency stimulation in hippocampus, the ROD values of individual hippocampal regions were normalized to the values of the surrounding cerebral cortex. For each animal, measurements were taken from three or four sections and averaged to generate a mean value for each area. Comparisons of means between groups (LTP, CPP, and sham) were performed using two-way ANOVA with laterality (ipsilateral vs contralateral) as the repeated measure, followed by post hoc Bonferroni $t$ tests. The probability levels interpreted as statistically significant were $p<0.05$.

Statistical analyses. All statistical analyses were done with SigmaStat 2.03 (SPSS, Chicago, IL). For the relative quantitative RT-PCR and Northern blot, each experimental group consisted of at least three animals. One-way ANOVA, followed by Bonferroni $t$ tests, was used for comparisons between groups; $p<0.05$ is considered significant. To determine the correlation between mRNA expression levels and potentiation among all three experimental groups, the Pearson correlation analysis was performed. The potentiation was measured by changes in fEPSP slope magnitudes. 


\section{Results}

Induction of NMDA receptor-dependent LTP in the Schaffer collateral-CA1 pathway in vivo

To identify the altered gene expression associated with synaptic plasticity at the Schaffer collateral $\rightarrow$ CA1 synapse, we induced robust and sustained potentiation of synaptic responses (fEPSP, $149.6 \pm 6.9 \%$ of baseline at $1 \mathrm{hr} ; p<0.001$; Fig. $1 A$ ) using strong tetanic stimulation. The potentiation of fEPSPs can last longer than $3 \mathrm{hr}$ (fEPSP, $160.1 \pm 1.6 \%$ at $1 \mathrm{hr} ; p=0.024 ; 157.1 \pm 16.0 \%$ at $3 \mathrm{hr} ; p=0.029$; Fig. $1 C$ ). Sham control animals (fEPSP, $103.5 \pm 4.4 \%$ at $1 \mathrm{hr} ; p=0.596$; Fig. $1 A$ ) received only lowfrequency stimulation $(0.05 \mathrm{~Hz})$.

In the CA1 area, the most commonly studied form of LTP induced by either one or multiple trains of high-frequency stimulation $(100 \mathrm{~Hz})$ is dependent on NMDA receptor activation (Harris et al., 1984). However, other forms of LTP that are not mediated by the NMDA receptor also have been reported in the CA1 area, such as NMDA receptor-independent LTP induced with very high-frequency $(200 \mathrm{~Hz})$ stimulation (Grover and Teyler, 1990), which requires the activation of voltage-gated calcium channels. To confirm that the LTP we observed here is mediated by NMDA receptor activation, we examined the induction of LTP under conditions of NMDA receptor blockade. The competitive NMDA receptor antagonist CPP $(10 \mathrm{mg} / \mathrm{kg})$ was intraperitoneally administered at least $1 \mathrm{hr}$ before delivery of trains, and LTP and sham animals received only intraperitoneal saline (vehicle) injection. As shown in Figure $1 B$, potentiations of the fEPSP slopes in CPP-treated animals were completely blocked $(100.4 \pm 5.6 \%$ of baseline; $p=0.943)$. Two-way ANOVA with high-frequency stimulation (before and after) as the repeated measure indicated a significant difference among the three groups $\left(\mathrm{LTP}, \mathrm{CPP}\right.$, and sham; group $\times$ stimulation effect, $F_{(2,9)}=$ 20.042; $p<0.001)$. Post hoc Bonferroni $t$ tests showed that $1 \mathrm{hr}$ after high-frequency stimulation, fEPSPs in LTP animals differed significantly from those in CPP animals $(p<0.001)$ and sham animals $(p<0.001)$, but there was no significant difference between CPP and sham controls $(p=1.000)$.

Isolation of genes upregulated by late-phase LTP

Three hours after the establishment of LTP, the brains were removed, and dissections were performed to obtain the ipsilateral tetanized hippocampi. The cDNA subtraction library was constructed to enrich genes upregulated during the development of prolonged LTP in vivo. Twenty-two positive bacterial colonies from the subtracted library were randomly picked, and partial sequencing reactions were performed to obtain the first 100-200 bp from each end of the insert cDNA. Because the tester and driver $\mathrm{CDNAs}$ were digested with a four-base-cutting restriction enzyme (RsaI), insert cDNAs ranged in sizes between 200 and 500 bp. These sequences were used to search the GenBank databases and to determine the identities of the subtracted cDNAs. Sequences that were already described in the databases were readily identified. In cases in which the sequence in question was novel, the homology data served to determine a potential function for these cDNAs.

Although the PCR-select subtraction method greatly enriched the differentially expressed genes, the subtracted sample still contained some cDNAs that corresponded to mRNAs common to both the tester and driver samples. Thus, those cDNAs were used as probes and screened by Northern blot analysis with pooled total RNA $(n=4)$ to eliminate any false-positive results. A $701 \mathrm{bp}$ clone that hybridized to LTP RNA more strongly than to the sham control in the Northern blot (data not shown) was identi-
A

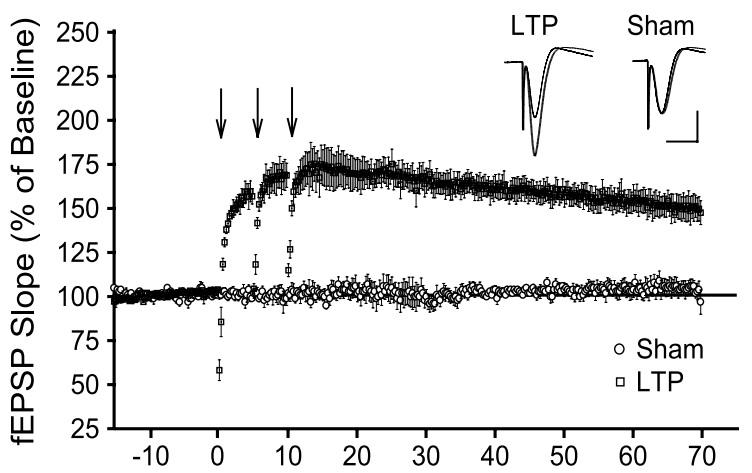

B
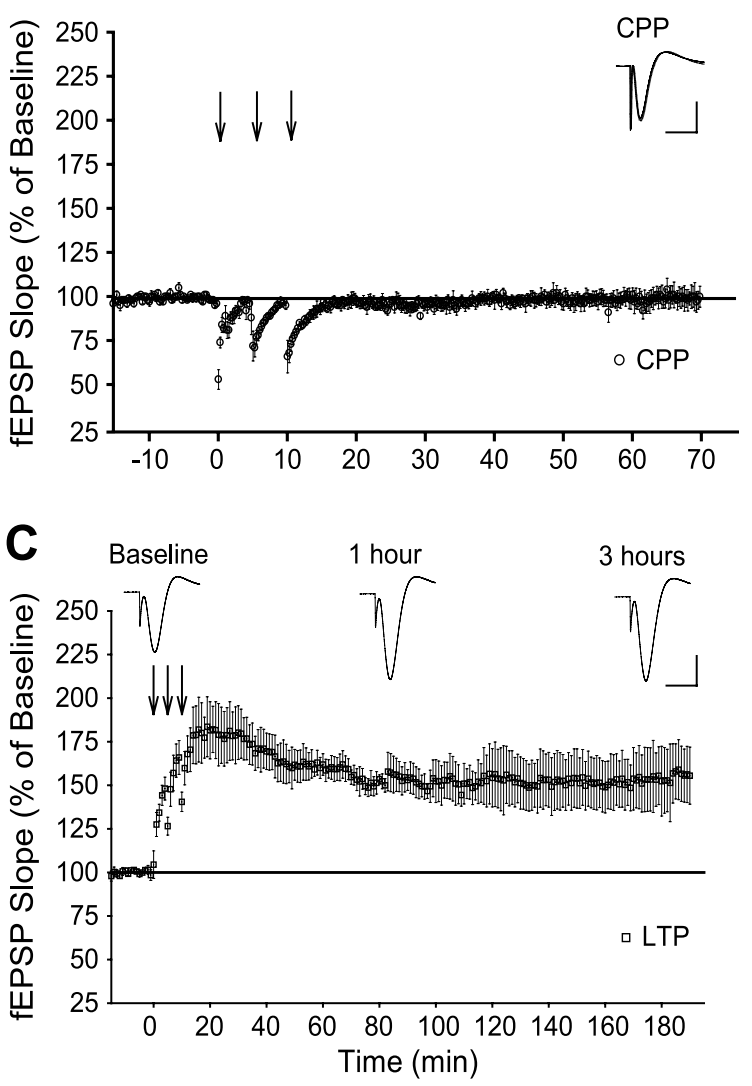

Figure 1. NMDA receptor-dependent LTP induction at the rat Schaffer-CA1 pathway in vivo. $A$, High-frequency stimulation induced LTP in the Schaffer-CA1 pathway. The plot shows field EPSP slope magnitudes of Schaffer-CA1 responses evoked at current intensities eliciting responses $50 \%$ of maximal. Values are group means \pm SEM expressed as percentage of baseline. Sham control animals $(n=4)$ received only low-frequency stimulation $(0.05 \mathrm{~Hz})$. Delivery of trains of high-frequency stimulation (three $1 \mathrm{sec}, 100 \mathrm{~Hz}$ trains with two 5 min intertrain intervals) to the Schaffer collaterals induced LTP $(n=4)$. $B$, High-frequency stimulation-induced LTP in the Schaffer-CA1 pathway was blocked by CPP. The potentiation was blocked when the competitive NMDA receptor antagonist CPP $(10 \mathrm{mg} / \mathrm{kg})$ was intraperitoneally injected $1 \mathrm{hr}$ before tetanus $(n=4)$. C, High-frequency stimulation-induced LTP lasted for $3 \mathrm{hr}$. Each data point corresponds to the average of four consecutive neuronal responses recorded at $15 \mathrm{sec}$ intervals $(n=3)$. Traces (averaged from five consecutive waveforms) are representative Schaffer-CA1 responses just before tetanus and $1 \mathrm{hr}$ after. Calibration: $1.0 \mathrm{mV}, 20 \mathrm{msec}$.

fied as the rat SCG10 gene (accession number AF306458) with $100 \%$ of sequence similarity, and primary nucleotide sequence comparison using the BLAST 2 program of the National Center for Biotechnology Information also showed 98\% identity be- 
A

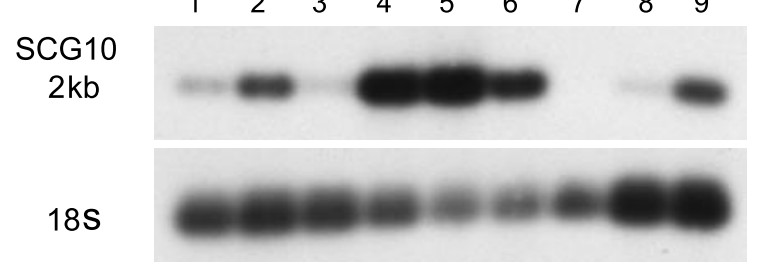

B

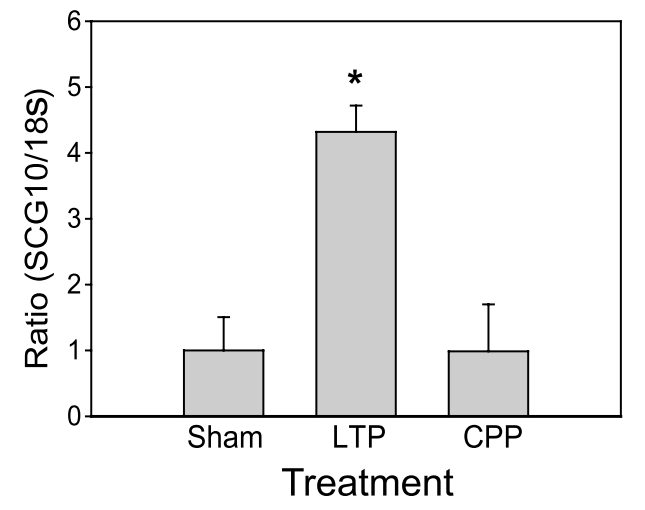

Figure 2. Semiquantitative RT-PCR analysis of the SCG10 mRNA $2 \mathrm{~kb}$ isoform. A, Autoradiograph of the SCG10 and internal control 18 S CDNA bands. The analysis of the gene expression levels by relative quantitative RT-PCR was performed using the primers specific to the nucleotide sequence of rat SCG10 mRNA 3'-UTR. Total RNAs were extracted from the ipsilateral hippocampi of individual sham (lanes 1-3), LTP (lanes 4-6), and (PP (lanes 7-9) animals. Simultaneously, the internal control 185 rRNA was also amplified in the same tubes with an optimal ratio of 185 primers and competimers (1:9). Top, The Southern blot of RT-PCR products was probed with a CDNA fragment corresponding to the rat SCG10 3'-UTR. Bottom, The RT-PCR products of 185 ribosomal RNA were also probed with 185 CDNA. B, These data were quantified using imaging densitometry and represented as ratios of $S C G 10$ to $18 \mathrm{~S}$ rRNA. The ratios were further normalized to the mean of the sham controls. LTP animals $(n=3 ; p=0.017)$ have a significantly higher level of the $2 \mathrm{~kb}$ transcripts than do sham controls $(n=3)$. CPP $(n=3)$ blocked the increase of SCG10 expression.

tween the $3^{\prime}$-UTR (bases 821-1520) of the rat SCG10 gene reported by Stein et al. (1988a) and this cDNA clone.

\section{Quantitative measurement of the altered expression of the SCG10 gene}

To confirm further the upregulated expression of the SCG10 gene associated with long-lasting LTP, relative RT-PCR analysis was used to quantitatively estimate the SCG10 mRNA levels. Each PCR reaction contained gene-specific primers that amplified a $600 \mathrm{bp}$ fragment corresponding to the 3'-UTR of the SCG10 mRNA (bases 917-1513) and internal control primers (18S primer pair and $18 \mathrm{~S}$ competimer) that produced a $324 \mathrm{bp}$ band of $18 \mathrm{~S}$ ribosomal RNA. The PCR products in the agarose gels were blotted to a nylon membrane and probed with SCG10 or 18S cDNA separately. The statistical analysis revealed that SCG10 gene expression was $4.32 \pm 0.40$-fold higher in LTP animals $\left(F_{(2,6)}=11.977 ; p=0.017\right)$ compared with the control untetanized animals (1.00 \pm 0.51 ; Fig. 2). The SCG10 mRNA levels were positively correlated with the degrees of synaptic enhancement, as measured by the changes in fEPSP slopes $1 \mathrm{hr}$ after tetanus $(r=$ $0.968 ; p<0.001)$.

The SCG10 protein is encoded by two mRNA isoforms ( 1 and $2 \mathrm{~kb}$ ) that differ in their choice of polyadenylation signal (Stein et al., 1988a), a characteristic of brain-specific mRNAs (Sutcliffe, 1988). Hannan et al. (1996) also found that the two SCG10 mRNA isoforms were differentially regulated during the onset of neurite outgrowth in early rat cerebellum development. Because

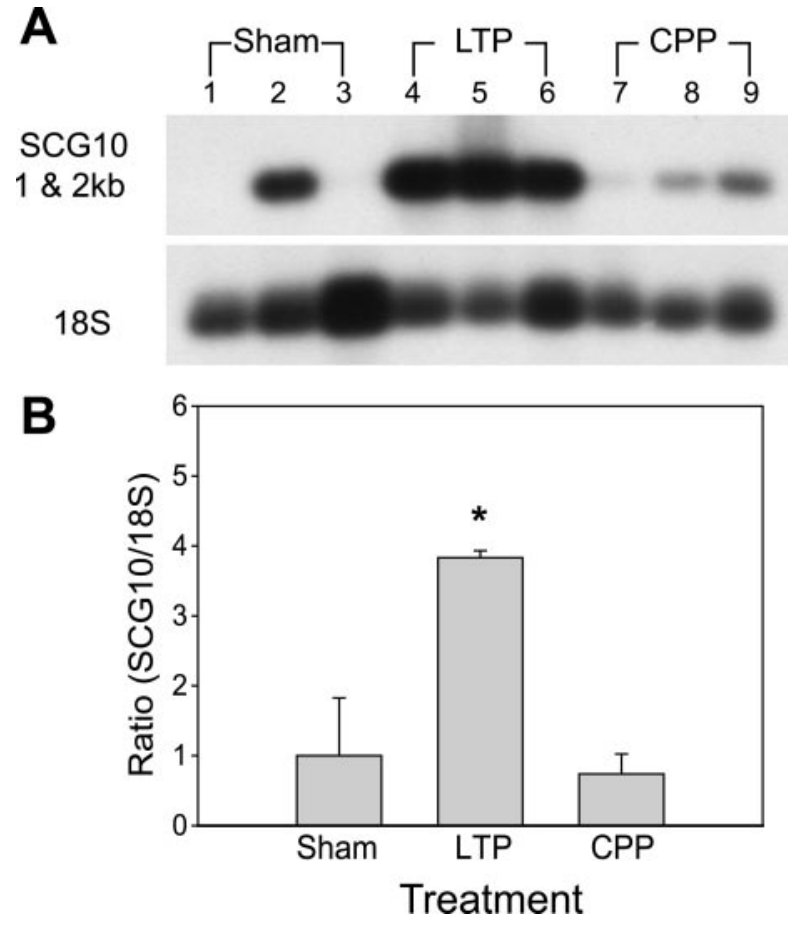

Figure 3. Semiquantitative RT-PCR analysis of SCG10 mRNA 1 and $2 \mathrm{~kb}$ isoforms. A, Autoradiograph of the SCG10 and internal control 18S CDNA bands. The analysis of the gene expression levels by RT-PCR was performed using the primers specific to the nucleotide sequence of the rat SCG10 mRNA coding region. Total RNAs were extracted from the ipsilateral hippocampi of individual sham (lanes 1-3), LTP (lanes 4-6), and CPP (lanes 7-9) animals. Simultaneously, a $324 \mathrm{bp}$ fragment of $18 \mathrm{~S}$ ribosomal RNA was amplified in the same tubes with the optimal ratio of 185 primers and competimers (1:19) as the internal control. Top, The Southern blot of RT-PCR products was probed with a CDNA fragment corresponding to the rat SCG10 coding region. Bottom, The RT-PCR products of 185 ribosomal RNA were also probed with 18S CDNA. B, These data were quantified using imaging densitometry and represented as ratios of SCG10 to $18 \mathrm{~S}$ rRNA. The ratios were further normalized to the sham controls. LTP animals $(n=3 ; p=0.023$ ) have a significantly higher level of both 1 and $2 \mathrm{~kb}$ transcripts than do sham controls $(n=3)$. CPP $(n=3)$ blocked the increase of the SCG10 expression.

the primers used in the first RT-PCR experiment were specific to the $3^{\prime}$-UTR of the SCG10 gene, it provided evidence only for the $2 \mathrm{~kb}$ form. To investigate whether the expression of the $1 \mathrm{~kb}$ form is also differentially regulated by late-phase LTP, we designed a new pair of gene-specific primers that amplify a $566 \mathrm{bp}$ sequence in the coding region (bases 101-666), which is common to both 1 and $2 \mathrm{~kb}$ isoforms. The quantification on the imaging densitometry indicated a threefold increase of the level of both mRNA transcripts $\left(3.83 \pm 0.10 ; F_{(2,6)}=11.412 ; p=0.023\right)$ associated with the late-phase LTP compared with sham controls (1.00 \pm 0.83 ; Fig. 3). There was also a significant correlation with the potentiation $(r=0.906 ; p<0.001) 1 \mathrm{hr}$ after tetanus.

Next, we used Northern analysis to demonstrate separately the relative abundance of the two forms of transcripts between tetanized and untetanized animals on the same blot. The riboprobe we used has a nucleotide sequence corresponding to the coding region of the SCG10 gene; thus it hybridized to both the 1 and 2 $\mathrm{kb}$ transcripts (Fig. $4 A$ ). The results were quantified using imaging densitometry and normalized as ratios of SCG10 to control $28 \mathrm{~S}$ rRNA (Fig. 4 B). The transcripts of $2 \mathrm{~kb}$ are more abundantly expressed in adult rat hippocampus than are those of the $1 \mathrm{~kb}$ form. Also, LTP animals have significantly higher levels of both transcripts $\left(2 \mathrm{~kb}, 1.53 \pm 0.09 ; F_{(2,6)}=20.357 ; p=0.007 ; 1 \mathrm{~kb}\right.$, $\left.1.79 \pm 0.09 ; F_{(2,6)}=32.290 ; p=0.001\right)$ than do sham controls $(2$ $\mathrm{kb}, 1.00 \pm 0.06 ; 1 \mathrm{~kb}, 1.00 \pm 0.08)$. These results indicate that 

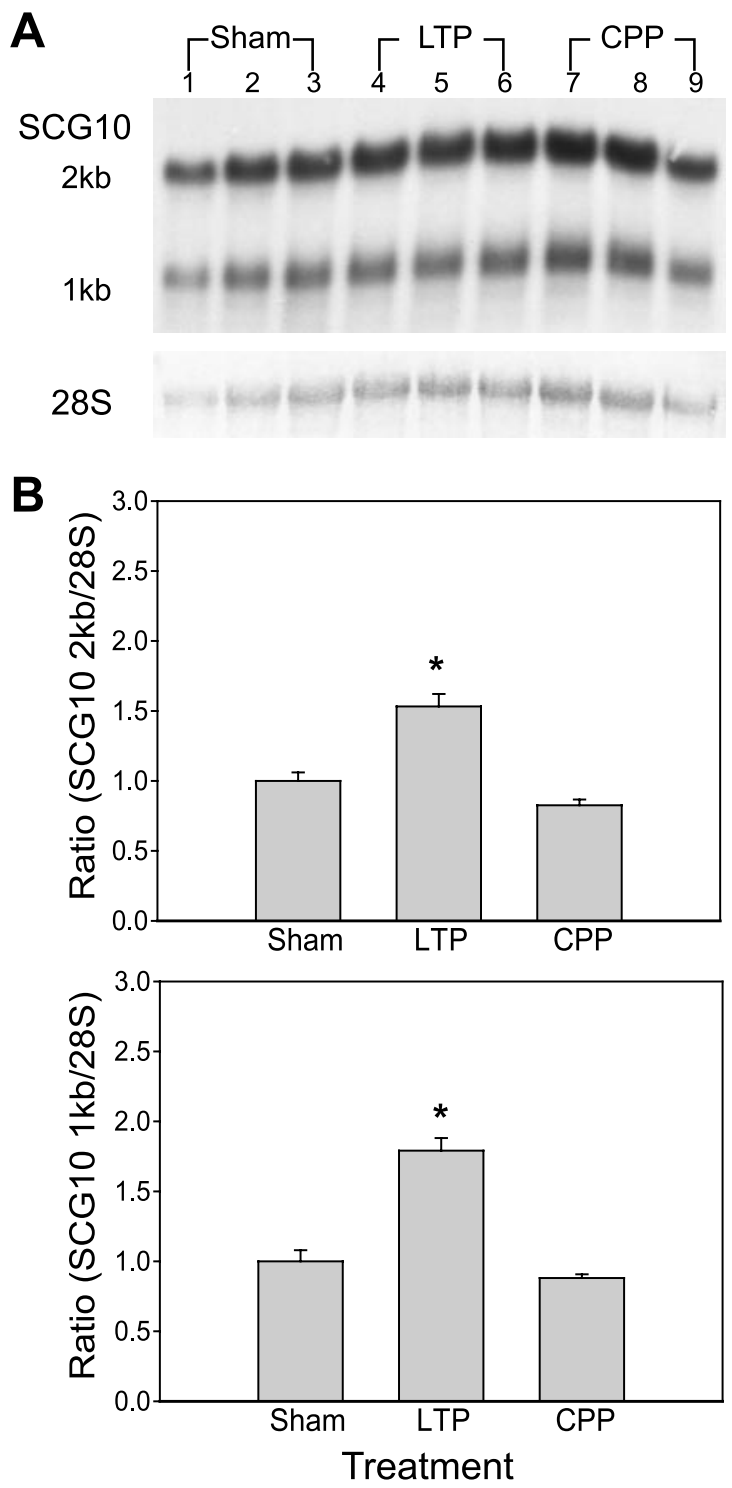

Figure 4. Northern analysis of SCG10 mRNA expression in the hippocampus. A, A Northern blot containing $10 \mu \mathrm{g}$ of total RNA from individual rat hippocampi was hybridized with a riboprobe corresponding to the sequence of the rat $\mathrm{SCG} 10$ coding region. Top, Lanes $1-3$, sham; lanes 4-6, LTP; lanes 7-9, CPP. Bottom, The Northern blot was stained with methylene blue. B, The data were quantified using imaging densitometry and represented as ratios of SCG10 to $28 \mathrm{~S}$ rRNA. The ratios were further normalized to the sham controls. LTP animals $(n=3)$ have a significantly higher level of both the $2 \mathrm{~kb}$ ( $p=0.007$; top) and $1 \mathrm{~kb}(p=0.001$; bottom) transcripts than do sham controls $(n=3)$. CPP $(n=3)$ blocked the elevation of the SCG10 expression.

both transcripts ( 1 and $2 \mathrm{~kb}$ ) of the SCG10 gene contribute to the upregulation of the SCG10 gene associated with late-phase LTP expression at the hippocampal Schaffer-CA1 pathway in vivo. The fold changes measured by Northern analysis were smaller than measured by the RT-PCR method, possibly because of the difference of sensitivity between the two methods. Consistent with the RT-PCR results, there was also a significant correlation between SCG10 mRNA expression levels and fEPSP magnitudes ( $2 \mathrm{~kb}, r=0.840 ; p<0.01 ; 1 \mathrm{~kb}, r=0.879$; $p<0.01$ ).

The change of SCG10 expression is mediated by the activation of NMDA receptors

The LTP induction in the hippocampal Schaffer collateral pathway is dependent on activation of NMDA receptors (Collingridge et al., 1983). If the Schaffer-CA1 LTP induction is blocked by a competitive NMDA receptor antagonist, then differential expression of genes associated with CA1 LTP induction will be expected to be blocked as well. Here, we used CPP to verify whether the SCG10 gene expression is regulated by NMDA receptordependent LTP induction.

The competitive NMDA receptor antagonist CPP is widely used to block the induction of LTP in many pathways in the brain (Hernandez et al., 1994; Davis et al., 1997; Hrabetova and Sacktor, 1997; Escobar et al., 1998). Compared with another competitive NMDA receptor antagonist, AP-5, CPP readily crosses the blood-brain barrier (Lehmann et al., 1987); thus CPP is especially suited for the study of the effects of systemically administered NMDA antagonists on CNS processes.

LTP induction in the Schaffer collateral pathway was blocked completely by intraperitoneal injection of CPP (Fig. $1 \mathrm{~B}$ ). Moreover, CPP blocked the elevation of SCG10 expression, as demonstrated by semiquantitative RT-PCR ( $2 \mathrm{~kb}, 0.99 \pm 0.71 ; p=1$; Fig. 2 ; $1 \mathrm{~kb}, 0.74 \pm 0.29 ; p=1$; Fig. 3$)$ and Northern analysis $(2$ $\mathrm{kb}, 0.83 \pm 0.04 ; p=0.36 ; 1 \mathrm{~kb}, 0.88 \pm 0.03 ; p=0.74$; Fig. 4 ).

\section{Spatial expression patterns of the gene during the development of LTP}

After the confirmation of differential expression of the SCG10 gene, we used in situ hybridization studies to determine its anatomical localization. Coronal brain sections through the hippocampus from sham, LTP, and CPP animals were probed with the antisense nucleotide corresponding to the $3^{\prime}$-UTR sequence of the SCG10 $2 \mathrm{~kb}$ transcript. SCG10 $2 \mathrm{~kb}$ mRNA is highly expressed in the hippocampus, with most prominent expression at the CA3 area and less expression in the CA1 and dentate gyrus areas (Fig. 5). Two-way ANOVA (group $\times$ laterality) with the laterality (ipsilateral and contralateral) as the repeated measure revealed a significant effect of group $\times$ laterality in the CA3 area $\left(F_{(2,6)}=10.323 ; p=0.011\right.$; Fig. $\left.6 A\right)$ and CA1 $\left(F_{(2,6)}=12.295 ; p=\right.$ 0.008 ; Fig. $6 B)$ but not the dentate gyrus $\left(F_{(2,6)}=0.420 ; p=\right.$ 0.675; Fig. 6C). Post hoc analysis showed a significant increase of the expression of $2 \mathrm{~kb}$ SCG10 mRNA in the ipsilateral CA3 region (LTP, $2.34 \pm 0.14$; sham controls, $1.71 \pm 0.02 ; p<0.001$; Fig. $6 A)$ and CA1 region (LTP, $1.21 \pm 0.02$; sham controls, $0.99 \pm$ $0.02 ; p<0.001$; Fig. $6 A$ ), which was blocked by the NMDA receptor antagonist $\mathrm{CPP}(\mathrm{CA} 3,1.57 \pm 0.05 ; p<0.001$; CA1, $1.04 \pm 0.03 ; p=0.004)$. The Pearson correlation analysis also indicated a significant correlation between SCG10 mRNA levels and magnitudes of LTP in these two subregions (CA3, $r=0.945$; $p<0.001$; CA1, $r=0.967 ; p<0.001)$. In the contralateral hippocampus, no significant effects of LTP induction were found in CA3 (Fig. 6A), CA1 (Fig. 6B), or the dentate gyrus (Fig. 6C).

\section{Discussion}

In present study, an NMDA receptor-dependent LTP lasting for $>3 \mathrm{hr}$ was induced by high-frequency stimulation in rat hippocampal Schaffer-CA1 pathway in vivo. By constructing a cDNA subtraction library, which is enriched in mRNAs upregulated $3 \mathrm{hr}$ after LTP induction, we identified a neural growthassociated protein SCG10 gene.

\section{SCG10 and synaptic plasticity}

On the basis of sequence similarity, neuron-specific SCG10 is related to the ubiquitous $19 \mathrm{kDa}$ stathmin protein (Schubart et al., 1989). Like stathmin, SCG10 also is a phosphoprotein that is a substrate for protein kinase A, mitogen-activated protein kinase, cyclin-dependent kinase, cGMP-dependent kinase, and cal- 

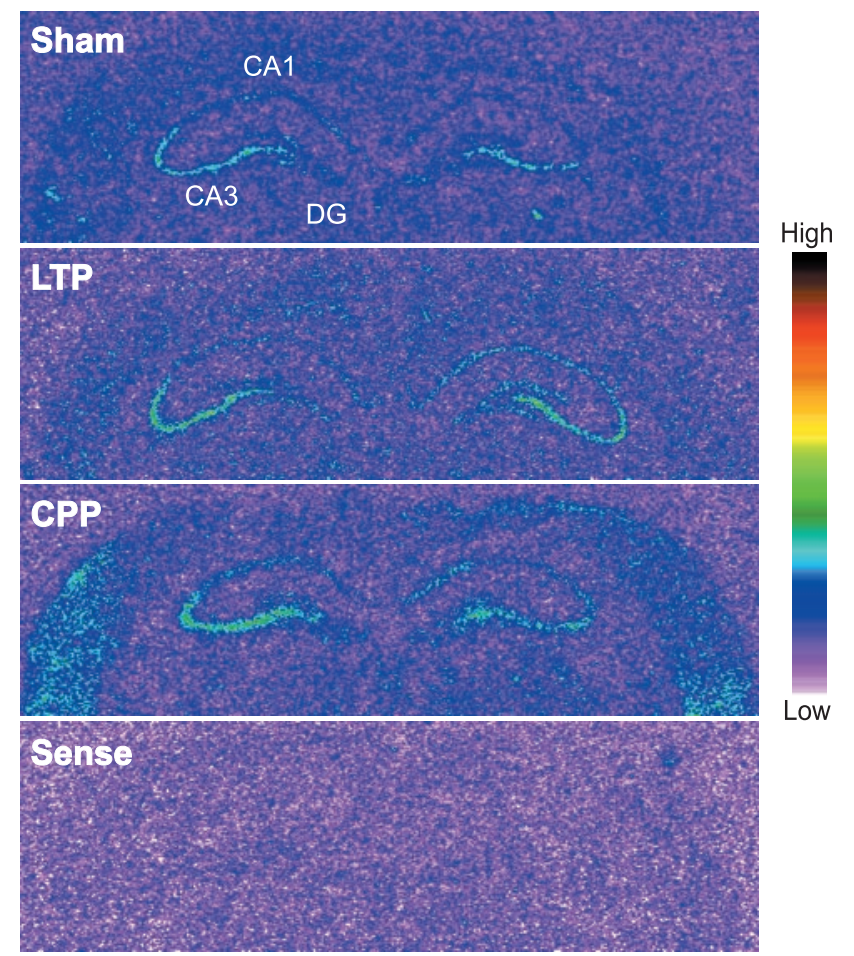

Figure 5. Densitometric images of the in situ hybridization autoradiographs showing different subregional expression patterns of the SCG10 $2 \mathrm{~kb}$ mRNA in the rat hippocampus. Coronal sections $(8 \mu \mathrm{m})$ through the hippocampus from sham, LTP, and CPP were probed with the antisense nucleotide corresponding to the sequence of the SCG103' -UTR. Sense, Coronal brain sections were probed with the $S \mathrm{CG} 10$ sense riboprobe as a negative control. The relative hybridization level is indicated by the color scale on the right. The electrodes were placed in the right hippocampus.

cium/calmodulin kinase, which can change phosphorylation levels of the SCG10 protein in response to extracellular signals such as NGF (Antonsson et al., 1997; Neidhart et al., 2001). The temporal and spatial expression patterns of SCG10 mRNA resemble those encoding other nGAPs, such as GAP-43 (De la Monte et al., 1989), microtubule-associated protein 2 (MAP-2; Tucker et al., 1989), and tau (Takemura et al., 1991), and those encoding synaptic vesicle-specific proteins, such as synapsin I (Melloni et al., 1993) and synaptophysin (Marqueze-Pouey et al., 1991). Particularly, SCG10 shares various regulated expression profiles with GAP-43. For instance, they are both enriched in the growth cone, developmentally regulated, induced by NGF, suppressed by glucocorticoids, and upregulated during axonal growth and regeneration and show significant expression in the adult brain areas involved in synaptic plasticity, such as hippocampus (Anderson and Axel, 1985; Stein et al., 1988a,b; Himi et al., 1994a; Higo et al., 1998; Pellier-Monnin et al., 2001). In addition to neurite extension, GAP-43 has been suggested to be involved in a variety of neuronal plasticity mechanisms, including LTP, in the hippocampus via synaptic remodeling (Meberg et al., 1993, 1995; Benowitz and Routtenberg, 1997; Routtenberg et al., 2000). Thus, SCG10 may also have a similar role in the adult brain.

In this study, we provided the first direct evidence to show the correlation of increased SCG10 gene transcription and LTP maintenance. The SCG10 protein is encoded by two mRNA isoforms, 1 and $2 \mathrm{~kb}$ in length, which differ in their polyadenylation site selection (Stein et al., 1988a). A previous study by Hannan et al. (1996) showed that expression of these two isoforms is temporally and spatially different during development. The higher
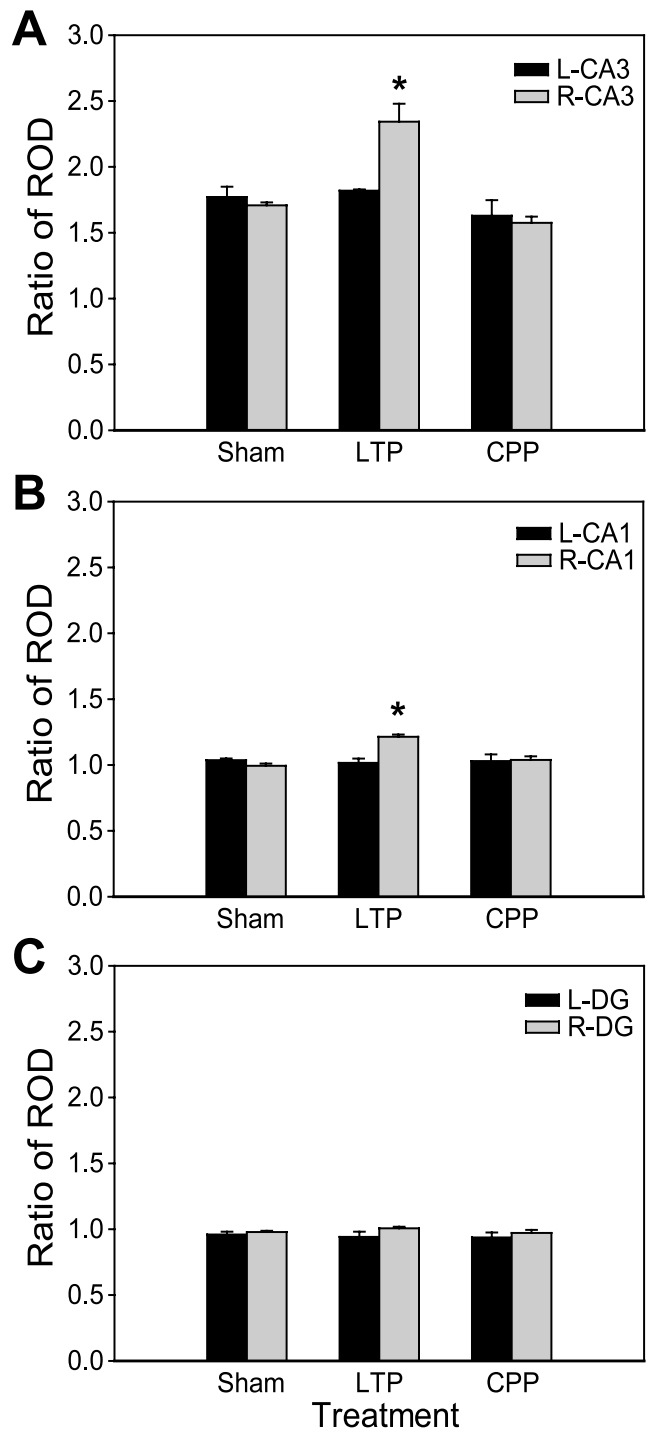

Figure 6. In vivo LTP induction elevated SCG10 $2 \mathrm{~kb}$ mRNA expression in the ipsilateral CA3 and CA1 regions. The autoradiographs of in situ hybridization were quantified using imaging densitometry and represented as ROD ratios of hippocampal subregions to their surrounding cerebral cortex. $A, B$, LTP animals $(n=3)$ have a significantly higher level of $2 \mathrm{~kb}$ transcripts than do sham controls $(\mathrm{n}=3)$ at the hippocampal CA3 $(p<0.001)$ and CA1 $(p<0.001)$ regions of the stimulated hemisphere. CPP $(n=3)$ blocked the increase of SCG10 mRNA expression. C, No significant alteration of SCG10 mRNA expression was detected in the dentate gyrus. L, Contralateral hippocampus (Fig. 5, left); R, ipsilateral hippocampus (Fig. 5, right).

level of $2 \mathrm{~kb}$ mRNA in our Northern analysis is consistent with their observation. Furthermore, our results also showed that the expression of both 1 and $2 \mathrm{~kb}$ forms of SCG10 mRNA increased as measured $3 \mathrm{hr}$ after LTP induction in the Schaffer-CA1 area in vivo.

However, our results are in contrast to findings of Beilharz et al. (1998). They found that transcription of RB3, another neuralspecific stathmin family protein, but not SCG10, increased after LTP induction in the perforant-dentate gyrus pathway. This difference may be attributable to the differences in LTP among these synaptic populations (Allen et al., 2000; Matthies et al., 2000; Song et al., 2001). In rat hippocampus, whereas RB3 mRNA is evenly expressed, SCG10 is less abundant in the dentate gyrus (Ozon et al., 1999). Thus SCG10 may play a less important role in synaptic plasticity in the dentate gyrus compared with the Schaffer-CA1 pathway. Although RB3 and SCG10 proteins contain the 
same stathmin-like domain, Charbaut et al. (2001) showed that each stathmin-like domain has specific biochemical and tubulin interaction properties; they display different developmental, regional, and functional regulations (Sugiura and Mori, 1995; Ozon et al., 1997, 1999). Thus, RB3 and SCG10 may have partially distinct and possibly complementary roles in relation to the control of development, plasticity, and neuronal activity.

In our in situ experiment, we observed a strong correlation between Schaffer-CA1 LTP and SCG10 mRNA elevation at the ipsilateral CA3 and CA1 areas, whereas no significant changes were detected at the ipsilateral dentate gyrus and in the contralateral hippocampus. Previous studies showed that the CA3 neurons project to the CA1 field through Schaffer collaterals (Anderson et al., 1971). The increase of SCG10 mRNA expression in both CA 3 and CA1 areas seems to suggest a dual (presynaptic and postsynaptic) or even a postsynaptic mechanism for the SCG10 protein because high-frequency stimulation in the Schaffer collaterals can activate CA3 neurons both antidromically and orthodromically (Buzsaki and Eidelberg, 1982), which makes these neurons both presynaptic and postsynaptic elements. However, because the SCG10 protein highly accumulates in presynaptic nerve terminals (Stein et al., 1988a; Lutjens et al., 2000; Gavet et al., 2002) just like the presynaptic protein GAP-43, we propose that SCG10 is more likely to be involved in presynaptic mechanisms of LTP maintenance. Although we did not measure the changes of the SCG10 protein level, in vivo studies by others (McNeill et al., 1999) do show that expression of the SCG10 protein in the axon terminals is highly correlated with expression of its mRNA in the neuronal cell body. The increase of SCG10 in CA1 cells may reflect polysynaptic LTP at CA1 targets, with the CA1 serving as the presynaptic element.

\section{SCG10 may play a role in synaptic remodeling by regulating neuronal cytoskeleton reorganization}

Although LTP induction is attributed to quick and transient local modification of transmission efficacy, the maintenance of LTP may depend on structural modifications of existing synapses or the formation of new synapses (Chang and Greenough, 1984; Desmond and Levy, 1988; Geinisman et al., 1993; Toni et al., 1999; Weeks et al., 1999; 2000). Like neuritic growth (Letourneau, 1996), synaptic remodeling (Spira et al., 2001; Huntley et al., 2002) also depends on continuous cytoskeletal rearrangement. Thus, nGAP SCG10 may play a role in synaptic plasticity by regulating cytoskeleton rearrangement.

Microtubules, the major components of the cytoskeleton, provide neurons with architectural support and serve as railways for transportation between the cell body and nerve terminals. The dynamic state (transitions between growth and shrinkage) of microtubules is controlled by a variety of proteins, including microtubule assembly-promoting proteins such as the MAP family (Wiche et al., 1986) and disassembly-promoting proteins such as the stathmin family (Mitchison and Kirschner, 1988). For example, NGF-induced neurite growth is correlated with changes of both the expression levels and phosphorylation state of the MAP (Black et al., 1986; Brugg and Matus, 1988) and stathmin (Riederer et al., 1997) families of proteins. Synaptic plasticity such as LTP has similar effects on MAP-2 (Johnson and Jope, 1992; Fukunaga et al., 1996). High levels of neurotrophic factors and their receptors have also been observed in hippocampal neurons (Ringstedt et al., 1993; Lindsay, 1994), and their expression is essential for neural activities such as LTP (Patterson et al., 1992; Patterson et al., 1996; Morimoto et al., 1998). Thus, NGF may have some role in neurite elongation and synaptic remodeling via both transient post-translational modification and long-term regulation of gene expression, which influence microtubule dynamics. Here we propose a working model for SCG10 function during LTP maintenance. High-frequency stimulation of Schaffer collaterals induces NMDA receptor-dependent postsynaptic NGF release, which works as a retrograde messenger to regulate gene expression, including SCG10 in the presynaptic neurons. As a result of the elevated SCG10 levels, the highly dynamic cytoskeleton would favor vesicle transportation and morphological alterations in synapses, increases in the number of synaptic contacts, or both. Eventually, a decrease of SCG10 expression and the microtubule-assembly function of MAP-2 would lead to stabilization of the cytoskeleton and hence would result in maintenance of these modified or newly formed synapses.

Recently, Maekawa et al. (2001) reported that SCG10 is a major component of the brain-derived raft. Raft microdomains are lateral assemblies of sphingolipids, glycosphingolipids, and cholesterol present intracellularly and in the plasma membrane (Simons and Ikonen, 1997). The raft of brain origin exclusively contains tubulin as a major constituent (Maekawa et al., 1997). In contrast to the usual T2S complex with tubulin dimers, a certain proportion of SCG10 in the raft forms T1S with a tubulin monomer, suggesting that these SCG10 proteins may be involved in attaching neuronal rafts to the membrane by interacting with tubulins (Maekawa et al., 2001). Mobile raft microdomains are assembled in the Golgi region and transported to the distal plasma membrane (Simons and Ikonen, 1997), which coincides well with the intracellular localization of membrane-associated SCG10 proteins (Di Paolo et al., 1997). Thus, rafts may provide a route for membrane traffic, which can sort and traffic specific proteins between the Golgi complex and nerve terminals via secretory and endocytic pathways. Moreover, brain rafts contain other nGAPs (Maekawa et al., 1997) and many signaltransducing molecules (Tansey et al., 2000; Orito et al., 2001; Niethammer et al., 2002), suggesting that rafts function as relay stations in the intracellular signaling that is essential for neurite growth and synaptic rearrangement. Thus, SCG10 may be involved in synaptic remodeling via lipid rafts, which mediate membrane traffic and signaling events.

In summary, our RT-PCR and Northern analysis confirmed the upregulation of both 1 and $2 \mathrm{~kb}$ forms of SCG10 mRNA $3 \mathrm{hr}$ after LTP induction in hippocampus, and the regulation was mediated by NMDA receptor activation. The in situ hybridization also showed an elevated SCG10 $2 \mathrm{~kb}$ mRNA level in ipsilateral CA3 and CA1 areas. Taken together, these results suggest that SCG10 may play an important role in synaptic plasticity via remodeling presynaptic terminals.

\section{References}

Abraham WC, Dragunow M, Tate WP (1991) The role of immediate early genes in the stabilization of long-term potentiation. Mol Neurobiol 5:297-314.

Allen PB, Hvalby O, Jensen V, Errington ML, Ramsay M, Chaudhry FA, Bliss TV, Storm-Mathisen J, Morris RG, Andersen P, Greengard P (2000) Protein phosphatase-1 regulation in the induction of long-term potentiation: heterogeneous molecular mechanisms. J Neurosci 20:3537-3543.

Anderson DJ, Axel R (1985) Molecular probes for the development and plasticity of neural crest derivatives. Cell 42:649-662.

Anderson P, Bliss TV, Skrede KK (1971) Lamellar organization of hippocampal pathways. Exp Brain Res 13:222-238.

Antonsson B, Lutjens R, Di Paolo G, Kassel D, Allet B, Bernard A, Catsicas S, Grenningloh G (1997) Purification, characterization, and in vitro phosphorylation of the neuron-specific membrane-associated protein SCG10. Protein Expr Purif 9:363-371.

Antonsson B, Kassel DB, Di Paolo G, Lutjens R, Riederer BM, Grenningloh G 
(1998) Identification of in vitro phosphorylation sites in the growth cone protein SCG10: effect of phosphorylation site mutants on microtubuledestabilizing activity. J Biol Chem 273:8439-8446.

Beilharz EJ, Zhukovsky E, Lanahan AA, Worley PF, Nikolich K, Goodman LJ (1998) Neuronal activity induction of the stathmin-like gene RB3 in the rat hippocampus: possible role in neuronal plasticity. J Neurosci 18:9780-9789.

Benowitz LI, Routtenberg A (1997) GAP-43: an intrinsic determinant of neuronal development and plasticity. Trends Neurosci 20:84-91.

Black MM, Aletta JM, Greene LA (1986) Regulation of microtubule composition and stability during nerve growth factor-promoted neurite outgrowth. J Cell Biol 103:545-557.

Bliss TV, Lømo T (1973) Long-lasting potentiation of synaptic transmission in the dentate area of the anaesthetized rabbit following stimulation of the perforant path. J Physiol (Lond) 232:331-356.

Brugg B, Matus A (1988) PC12 cells express juvenile microtubuleassociated proteins during nerve growth factor-induced neurite outgrowth. J Cell Biol 107:643-650.

Buzsaki G, Eidelberg E (1982) Convergence of associational and commissural pathways on CA1 pyramidal cells of the rat hippocampus. Brain Res 237:283-295.

Chang FL, Greenough WT (1984) Transient and enduring morphological correlates of synaptic activity and efficacy change in the rat hippocampal slice. Brain Res 309:35-46.

Charbaut E, Curmi PA, Ozon S, Lachkar S, Redeker V, Sobel A (2001) Stathmin family proteins display specific molecular and tubulin binding properties. J Biol Chem 276:16146-16154.

Collingridge GL, Kehl SJ, McLennan H (1983) Excitatory amino acids in synaptic transmission in the Schaffer collateral-commissural pathway of the rat hippocampus. J Physiol (Lond) 334:33-46.

Davis S, Bliss TV, Dutrieux G, Laroche S, Errington ML (1997) Induction and duration of long-term potentiation in the hippocampus of the freely moving mouse. J Neurosci Methods 75:75-80.

De la Monte SM, Federoff HJ, Ng SC, Grabczyk E, Fishman MC (1989) GAP-43 gene expression during development: persistence in a distinctive set of neurons in the mature central nervous system. Dev Brain Res 46:161-168.

Desmond NL, Levy WB (1988) Synaptic interface surface area increases with long-term potentiation in the hippocampal dentate gyrus. Brain Res 453:308-314.

Di Paolo G, Lutjens R, Pellier V, Stimpson SA, Beuchat MH, Catsicas S, Grenningloh G (1997) Targeting of SCG10 to the area of the Golgi complex is mediated by its NH2-terminal region. J Biol Chem 272:5175-5182.

Dragunow M (1996) A role for immediate-early transcription factors in learning and memory. Behav Genet 26:293-299.

Escobar ML, Chao V, Bermudez-Rattoni F (1998) In vivo long-term potentiation in the insular cortex: NMDA receptor dependence. Brain Res 779:314-319.

Fukunaga K, Muller D, Miyamoto E (1996) CaM kinase II in long-term potentiation. Neurochem Int 28:343-358.

Gavet O, El Messari S, Ozon S, Sobel A (2002) Regulation and subcellular localization of the microtubule-destabilizing stathmin family phosphoproteins in cortical neurons. J Neurosci Res 68:535-550.

Geinisman Y, de Toledo-Morrell L, Morrell F, Heller RE, Rossi M, Parshall RF (1993) Structural synaptic correlate of long-term potentiation: formation of axospinous synapses with multiple, completely partitioned transmission zones. Hippocampus 3:435-445.

Grover LM, Teyler TJ (1990) Two components of long-term potentiation induced by different patterns of afferent activation. Nature 347:477-479.

Hannan AJ, Henke RC, Weinberger RP, Sentry JW, Jeffrey PL (1996) Differential induction and intracellular localization of SCG10 messenger RNA is associated with neuronal differentiation. Neuroscience 72:889-900.

Harris EW, Ganong AH, Cotman CW (1984) Long-term potentiation in the hippocampus involves activation of $\mathrm{N}$-methyl-D-aspartate receptors. Brain Res 323:132-137.

Hernandez RV, Derrick BE, Rodriguez WA, Martinez JL Jr (1994) (+/)CPP, an NMDA receptor antagonist, blocks the induction of commissural-CA3 LTP in the anesthetized rat. Brain Res 656:215-219.

Higo N, Oishi T, Yamashita A, Matsuda K, Hayashi M (1998) Gene expression of growth-associated proteins, GAP-43 and SCG10, in the hip- pocampal formation of the macaque monkey: nonradioactive in situ hybridization study. Hippocampus 8:533-547.

Himi T, Okazaki T, Mori N (1994a) SCG10 mRNA localization in the hippocampus: comparison with other mRNAs encoding neuronal growthassociated proteins (nGAPs). Brain Res 655:177-185.

Himi T, Okazaki T, Wang H, McNeill TH, Mori N (1994b) Differential localization of SCG10 and p19/stathmin messenger RNAs in adult rat brain indicates distinct roles for these growth-associated proteins. Neuroscience 60:907-926.

Hrabetova S, Sacktor TC (1997) Long-term potentiation and long-term depression are induced through pharmacologically distinct NMDA receptors. Neurosci Lett 226:107-110.

Huntley GW, Benson DL, Colman DR (2002) Structural remodeling of the synapse in response to physiological activity. Cell 108:1-4.

Johnson GV, Jope RS (1992) The role of microtubule-associated protein 2 (MAP-2) in neuronal growth, plasticity, and degeneration. J Neurosci Res 33:505-512.

Lanahan A, Worley P (1998) Immediate-early genes and synaptic function. Neurobiol Learn Mem 70:37-43.

Lehmann J, Schneider J, McPherson S, Murphy DE, Bernard P, Tsai C, Bennett DA, Pastor G, Steel DJ, Boehm C (1987) CPP, a selective N-methylD-aspartate (NMDA)-type receptor antagonist: characterization in vitro and in vivo. J Pharmacol Exp Ther 240:737-746.

Letourneau PC (1996) The cytoskeleton in nerve growth cone motility and axonal pathfinding. Perspect Dev Neurobiol 4:111-123.

Lindsay RM (1994) Neurotrophins and receptors. Prog Brain Res 103:3-14. Lutjens R, Igarashi M, Pellier V, Blasey H, Di Paolo G, Ruchti E, Pfulg C, Staple JK, Catsicas S, Grenningloh G (2000) Localization and targeting of SCG10 to the trans-Golgi apparatus and growth cone vesicles. Eur J Neurosci 12:2224-2234.

Maekawa S, Kumanogoh H, Funatsu N, Takei N, Inoue K, Endo Y, Hamada K, Sokawa Y (1997) Identification of NAP-22 and GAP-43 (neuromodulin) as major protein components in a Triton insoluble low density fraction of rat brain. Biochim Biophys Acta 1323:1-5.

Maekawa S, Morii H, Kumanogoh H, Sano M, Naruse Y, Sokawa Y, Mori N (2001) Localization of neuronal growth-associated, microtubuledestabilizing factor SCG10 in brain-derived raft membrane microdomains. J Biochem (Tokyo) 129:691-697.

Marqueze-Pouey B, Wisden W, Malosio ML, Betz H (1991) Differential expression of synaptophysin and synaptoporin mRNAs in the postnatal rat central nervous system. J Neurosci 11:3388-3397.

Martinez Jr JL, Derrick BE (1996) Long-term potentiation and learning. Annu Rev Psychol 47:173-203.

Matthies H, Schroeder H, Becker A, Loh H, Hollt V, Krug M (2000) Lack of expression of long-term potentiation in the dentate gyrus but not in the CA1 region of the hippocampus of mu-opioid receptor-deficient mice. Neuropharmacology 39:952-960.

McNeill TH, Mori N, Cheng HW (1999) Differential regulation of the growth-associated proteins, GAP-43 and SCG-10, in response to unilateral cortical ablation in adult rats. Neuroscience 90:1349-1360.

Meberg PJ, Barnes CA, McNaughton BL, Routtenberg A (1993) Protein kinase $\mathrm{C}$ and $\mathrm{F} 1 / \mathrm{GAP}-43$ gene expression in hippocampus inversely related to synaptic enhancement lasting 3 days. Proc Natl Acad Sci USA 90:12050-12054.

Meberg PJ, Valcourt EG, Routtenberg A (1995) Protein F1/GAP-43 and PKC gene expression patterns in hippocampus are altered $1-2 \mathrm{~h}$ after LTP. Brain Res Mol Brain Res 34:343-346.

Melloni Jr RH, Hemmendinger LM, Hamos JE, DeGennaro LJ (1993) Synapsin I gene expression in the adult rat brain with comparative analysis of mRNA and protein in the hippocampus. J Comp Neurol 327:507-520.

Mitchison T, Kirschner M (1988) Cytoskeletal dynamics and nerve growth. Neuron 1:761-772.

Morimoto K, Sato K, Sato S, Yamada N, Hayabara T (1998) Timedependent changes in neurotrophic factor mRNA expression after kindling and long-term potentiation in rats. Brain Res Bull 45:599-605.

Neidhart S, Antonsson B, Gillieron C, Vilbois F, Grenningloh G, Arkinstall S (2001) c-Jun N-terminal kinase-3 (JNK3)/stress-activated protein kinase-beta (SAPKbeta) binds and phosphorylates the neuronal microtubule regulator SCG10. FEBS Lett 508:259-264.

Nguyen PV, Abel T, Kandel ER (1994) Requirement of a critical period of transcription for induction of a late phase of LTP. Science 265:1104-1107. Niethammer P, Delling M, Sytnyk V, Dityatev A, Fukami K, Schachner M 
(2002) Cosignaling of NCAM via lipid rafts and the FGF receptor is required for neuritogenesis. J Cell Biol 157:521-532.

Orito A, Kumanogoh H, Yasaka K, Sokawa J, Hidaka H, Sokawa Y, Maekawa S (2001) Calcium-dependent association of annexin VI, protein kinase $\mathrm{C}$ alpha, and neurocalcin alpha on the raft fraction derived from the synaptic plasma membrane of rat brain. J Neurosci Res 64:235-241.

Ozon S, Maucuer A, Sobel A (1997) The stathmin family: molecular and biological characterization of novel mammalian proteins expressed in the nervous system. Eur J Biochem 248:794-806.

Ozon S, El Mestikawy S, Sobel A (1999) Differential, regional, and cellular expression of the stathmin family transcripts in the adult rat brain. J Neurosci Res 56:553-564.

Patterson SL, Grover LM, Schwartzkroin PA, Bothwell M (1992) Neurotrophin expression in rat hippocampal slices: a stimulus paradigm inducing LTP in CA1 evokes increases in BDNF and NT-3 mRNAs. Neuron 9:1081-1088.

Patterson SL, Abel T, Deuel TA, Martin KC, Rose JC, Kandel ER (1996) Recombinant BDNF rescues deficits in basal synaptic transmission and hippocampal LTP in BDNF knockout mice. Neuron 16:1137-1145.

Pellier-Monnin V, Astic L, Bichet S, Riederer BM, Grenningloh G (2001) Expression of SCG10 and stathmin proteins in the rat olfactory system during development and axonal regeneration. J Comp Neurol 433:239-254.

Riederer BM, Pellier V, Antonsson B, Di Paolo G, Stimpson SA, Lutjens R, Catsicas S, Grenningloh G (1997) Regulation of microtubule dynamics by the neuronal growth-associated protein SCG10. Proc Natl Acad Sci USA 94:741-745.

Ringstedt T, Lagercrantz H, Persson H (1993) Expression of members of the trk family in the developing postnatal rat brain. Brain Res Dev Brain Res 72:119-131.

Routtenberg A, Cantallops I, Zaffuto S, Serrano P, Namgung U (2000) Enhanced learning after genetic overexpression of a brain growth protein. Proc Natl Acad Sci USA 97:7657-7662.

Schubart UK, Banerjee MD, Eng J (1989) Homology between the cDNAs encoding phosphoprotein p19 and SCG10 reveals a novel mammalian gene family preferentially expressed in developing brain. DNA $8: 389-398$.

Simons K, Ikonen E (1997) Functional rafts in cell membranes. Nature 387:569-572.

Song D, Xie X, Wang Z, Berger TW (2001) Differential effect of TEA on long-term synaptic modification in hippocampal CA1 and dentate gyrus in vitro. Neurobiol Learn Mem 76:375-387.

Spira ME, Oren R, Dormann A, Ilouz N, Lev S (2001) Calcium, protease activation, and cytoskeleton remodeling underlie growth cone formation and neuronal regeneration. Cell Mol Neurobiol 21:591-604.

Stein R, Mori N, Matthews K, Lo LC, Anderson DJ (1988a) The NGFinducible SCG10 mRNA encodes a novel membrane-bound protein present in growth cones and abundant in developing neurons. Neuron $1: 463-476$

Stein R, Orit S, Anderson DJ (1988b) The induction of a neural-specific gene, SCG10, by nerve growth factor in PC12 cells is transcriptional, protein synthesis dependent, and glucocorticoid inhibitable. Dev Biol 127:316-325.

Sugiura Y, Mori N (1995) SCG10 expresses growth-associated manner in developing rat brain, but shows a different pattern to p19/stathmin or GAP-43. Dev Brain Res 90:73-91.

Sutcliffe JG (1988) mRNA in the mammalian central nervous system. Annu Rev Neurosci 11:157-198.

Takemura R, Kanai Y, Hirokawa N (1991) In situ localization of tau mRNA in developing rat brain. Neuroscience 44:393-407.

Tansey MG, Baloh RH, Milbrandt J, Johnson EM Jr (2000) GFRalphamediated localization of RET to lipid rafts is required for effective downstream signaling, differentiation, and neuronal survival. Neuron 25:611-623.

Toni N, Buchs PA, Nikonenko I, Bron CR, Muller D (1999) LTP promotes formation of multiple spine synapses between a single axon terminal and a dendrite. Nature 402:421-425.

Tucker RP, Garner CC, Matus A (1989) In situ localization of microtubuleassociated protein mRNA in the developing and adult rat brain. Neuron 2:1245-1256.

Walton M, Henderson C, Mason-Parker S, Lawlor P, Abraham WC, Bilkey D, Dragunow M (1999) Immediate early gene transcription and synaptic modulation. J Neurosci Res 58:96-106.

Weeks AC, Ivanco TL, Leboutillier JC, Racine RJ, Petit TL (1999) Sequential changes in the synaptic structural profile following long-term potentiation in the rat dentate gyrus: I. The intermediate maintenance phase. Synapse 31:97-107.

Weeks AC, Ivanco TL, Leboutillier JC, Racine RJ, Petit TL (2000) Sequential changes in the synaptic structural profile following long-term potentiation in the rat dentate gyrus. II. Induction/early maintenance phase. Synapse 36:286-296.

Wiche G, Herrmann H, Dalton JM, Foisner R, Leichtfried FE, Lassmann H, Koszka C, Briones E (1986) Molecular aspects of MAP-1 and MAP-2: microheterogeneity, in vitro localization and distribution in neuronal and nonneuronal cells. Ann NY Acad Sci 466:180-198. 